\title{
Arsenic Release From a Natural Rock under near-natural Oxidizing
}

(a) Georg-August-Universität Göttingen, Angewandte Geologie, Goldschmidtstrasse 3, 37077 Göttingen Germany.

(b) Ref. B 3.12 Angewandte Aero- und Bodengeophysik, Bundesanstalt für Geowissenschaften und Rohstoffe, Stilleweg 2, D-30655 Hannover - Germany.

(c) Technische Universität Bergakademie Freiberg, Institut für Mineralogie, Brennhausgasse 14, D-09596 Freiberg/Sachsen - Germany.

\section{Abstract}

The solubilization of arsenic (As) from an ore material (native Arsenic [As, trig.] with Lollingite $\left[\mathrm{FeAs}_{2}, \mathrm{rh}.\right]$ ) was characterized in leaching tests lasting for $\leq 99$ days. The experiments were performed with materials of different particle sizes $(\leq 2 \mathrm{~mm})$, in different waters and under test conditions relevant to As mobilization at near surface contaminated sites. The impact of dolomite $\left[\mathrm{CaMg}\left(\mathrm{CO}_{3}\right)_{2}\right]$, metallic iron $\left(\mathrm{Fe}^{0}\right)$, and pyrite $\left(\mathrm{FeS}_{2}\right)$ on As release was accessed. Two different types of batch experiments were conducted with a constant amount of the base material and different types of water (deionised, mineral, spring, and tap water). For comparison parallel experiments were conducted with $0.1 \mathrm{M}$ EDTA, 0.1M $\mathrm{Na}_{2} \mathrm{CO}_{3}$ and $0.1 \mathrm{M} \mathrm{H}_{2} \mathrm{SO}_{4}$. The results indicated no significant effect of carbonate addition on As solubilization. $\mathrm{Fe}^{0}$ and $\mathrm{FeS}_{2}$ addition essentially slowed the initial As solubilization. $\mathrm{H}_{2} \mathrm{SO}_{4}$ was the sole leaching agent significantly influencing As solubilization from the base material. The general trend assuming that "the smaller the particle size the quicker the As release" was not strictly verified because in samples of smaller particle sizes $(d<0.063)$ As was partly oxidized to more stable species.

Key Words: Carbonate, Native arsenic, Solubilization 


\section{Introduction}

The presence of arsenic (As) in many minerals, mining wastes, industrial wastewater and waterways is a serious pollution problem [1-4]. The treatment of such contaminated materials by conventional techniques is often expensive. A recent development to remediate such a contamination is the implementation of permeable reactive barriers [5-10]. Most of the current full-scale reactive barriers use metallic iron ( $\mathrm{Fe}^{0}$-based alloys widely termed as zerovalent iron) as treatment medium. An iron reactive barrier can be placed immediately down gradient of the contaminant source (e.g. mining wastes) to prevent a plume from developing. Arsenic is leached from mining wastes by infiltrating surface water or flowing groundwater to the reactive barrier. Therefore, to properly design a treatment wall, it is essential to characterize the leaching behaviour of natural waters for contaminant source materials (natural ores, mining wastes). The bicarbonate $\left(\mathrm{HCO}_{3}{ }^{-}\right)$content of subsurface waters has been controversially discussed in the literature as possible important parameter controlling their As mobilization capacity as discussed below.

In the last decades substantial efforts were made to elucidate the origin of As in contaminated groundwaters [1, 11-22]. The univocal result of these efforts is that As mostly originates from natural background sources. However, the individual processes leading to As release and their relative importance are yet to be fully elucidated [16, 23-28]. There are three main theories concerning As release into the environment [29-32]: (i) competitive exchange of bicarbonate, phosphate or silicate, (ii) oxidation of arsenic-bearing minerals, and (iii) reductive dissolution of iron and manganese hydroxides. The distribution of arsenic in the environment depends on the partitioning between the aqueous and solid phase. The main processes controlling the distribution are: (i) complex formation, (ii) adsorption/desorption, precipitation/dissolution, (iii) biotic and abiotic oxidation/reduction [18, 22, 29, 33].

The most common arsenic species in natural water, sediment, and groundwater are: (i) neutral arsenite $\left(\mathrm{As}(\mathrm{OH})_{3}{ }^{0}\right)$, and the negatively charged arsenate $\left(\mathrm{H}_{2} \mathrm{AsO}_{4}{ }^{-}\right.$and $\left.\mathrm{HAsO}_{4}{ }^{2-}\right)$. Native As 
$54\left(\mathrm{As}^{0}\right)$ and lower valent As-minerals $\left(\mathrm{As}^{-\mathrm{III}}\right.$ and $\left.\mathrm{As}^{-\mathrm{I}}\right)$ are stable only under strongly reducing 55 conditions. Arsenite $\left(A s^{\text {III }}\right.$ ) is more toxic to humans and has higher mobility in the environment than arsenate $\left(\mathrm{As}^{\mathrm{V}}\right)[27,34]$. The increased attention on the health effects due to consumption of As contaminated water has prompted a very strict maximum contaminant level $(\mathrm{MCL}=10 \mu \mathrm{g} / \mathrm{L})$. The mobility of As species and their adsorption by metal oxides and hydroxides have been reported to be strongly influenced by carbonate ions. This effect is usually attributed to competitive adsorption of carbonate and anionic $\mathrm{As}^{\mathrm{V}}$ species on available solid surfaces (e.g. ref. 35). However, Kim et al. [16] postulated the formation of As ${ }^{\text {III }}$ carbonate complexes, which increases the mobility of arsenic in anoxic aquifers [23, 36].

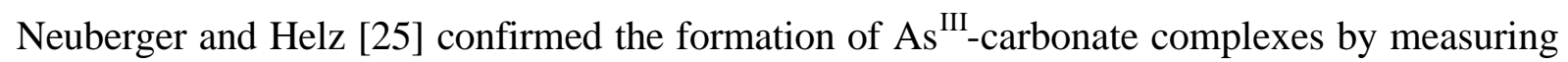
the solubility of $\mathrm{As}_{2} \mathrm{O}_{3}$ in concentrated carbonate solutions (up to $720 \mathrm{mM}$ as $\mathrm{HCO}_{3}{ }^{-}$). However, their data suggested that $\mathrm{As}^{\mathrm{III}}$-carbonate complexes will be negligible at $\mathrm{HCO}_{3}{ }^{-}$ concentrations found in most natural waters $(1.3$ to $5.5 \mathrm{mM})$. On the other hand Kim et al. [19] showed an acceleration of the oxidation of $\mathrm{As}^{\mathrm{III}}$-carbonate relative to non-complexed $\mathrm{As}^{\mathrm{III}}\left[\mathrm{As}(\mathrm{OH})_{3}{ }^{0}\right]$. These findings are conflicting with the hypothesis of Kim et al. [16] because stable $A s^{\mathrm{III}}$-complexes should impair As ${ }^{\mathrm{III}}$ oxidation. Therefore, the possibly important role of $\mathrm{As}^{\mathrm{III}}-\mathrm{HCO}_{3}{ }^{-}$complexes in natural waters remains to be properly addressed. An approach to this end is to characterize the solubility of As from a natural mineral containing $\mathrm{As}^{-\mathrm{III}}, \mathrm{As}^{-\mathrm{I}}$, $\mathrm{As}^{0}$ or $\mathrm{As}{ }^{\mathrm{III}}$ through waters with $\mathrm{HCO}_{3}{ }^{-}$contents pertinent to natural situations.

The objective of the present work is to contribute to the elucidation of the role of $\mathrm{As}^{\mathrm{III}}-\mathrm{HCO}_{3}{ }^{-}$ complexes in the process of As transport in the environment. For this purpose, the process of As release from a natural As-mineral by natural-near waters of various $\mathrm{HCO}_{3}{ }^{-}$contents under oxic conditions was characterised. The used As-ore contained mostly native arsenic $\left(\mathrm{As}^{0}\right)$ and Lollingite $\left(\mathrm{As}^{-\mathrm{I}}-\mathrm{FeAs}_{2}\right)$. Because As is stable in the aqueous phase as $\mathrm{As}^{\mathrm{III}}$ and $\mathrm{As}^{\mathrm{V}}$ and the experiments are performed under oxic conditions, it is expected that the stability of As ${ }^{\mathrm{III}}{ }_{-}$ 
section). The advantage of the used As-mineral (proxy for tailings materials) upon sediments used by for example by Anawar et al. [23] is its relative simple composition. The used waters content 0.0 to $30 \mathrm{mM} \mathrm{HCO}_{3}^{-}$.

\section{Background of the experimental methodology}

In arsenic tailings and mining wastes the As dissolution process typically involves oxidation and destabilization of As minerals such as native arsenic $\left(\mathrm{As}^{0}\right)$ possibly resulting in high concentrations of species stable under aqueous conditions ( $\mathrm{As}^{\mathrm{III}}$ and $\mathrm{As}{ }^{\mathrm{V}}$ ). The transport of $\mathrm{As}^{\mathrm{III}}$-species in natural waters (neutral $\mathrm{pH}$ range) has been reported to be influenced by the carbonate concentration $\left(\mathrm{HCO}_{3}{ }^{-}, \mathrm{P}_{\mathrm{CO} 2}\right)$ which forms complexes with $\mathrm{As}{ }^{\mathrm{III}}[19,23,36]$. As ${ }^{\mathrm{III}}$ complexation with $\mathrm{HCO}_{3}^{-}$should influence the further oxidation to $\mathrm{As}^{\mathrm{V}}$ [19]. In particular, in the presence of limited amounts of $\mathrm{HCO}_{3}^{-}, \mathrm{As}^{\mathrm{III}}$ oxidation to $\mathrm{As}^{\mathrm{V}}$ should be impaired if the complexes are more stable than $\mathrm{As}(\mathrm{OH})_{3}{ }^{0}$. However, Kim et al. [19] reported on the acceleration of the oxidation of carbonate-As ${ }^{\mathrm{III}}$ complexes in comparison to free $\mathrm{As}^{\mathrm{III}}$ $\left[\mathrm{As}(\mathrm{OH})_{3}{ }^{0}\right]$. Because $\mathrm{As}^{\mathrm{V}}$ species do no form complexes with $\mathrm{HCO}_{3}^{-}$, the net effect of $\mathrm{HCO}_{3}{ }^{-}$ ions should be the decrease of As release from used $\mathrm{As}^{0}$-mineral, as excess $\mathrm{As}^{\mathrm{V}}$ from oxidized carbonate-As ${ }^{\mathrm{III}}$ should precipitate as $\mathrm{As}^{\mathrm{V}}$ oxides. Alternatively excess $\mathrm{As}{ }^{\mathrm{V}}$ might remain in a meta-stable solution yielding higher As concentrations. Therefore, the effects of $\mathrm{HCO}_{3}{ }^{-}$on $\mathrm{As}^{0}$ release by natural-near waters may be summarized in a simple hypothesis: under oxic conditions and near-neutral $\mathrm{pH}$ value, the extent of As release from native arsenic is influenced (decreases or increases) by increasing $\mathrm{HCO}_{3}{ }^{-}$concentrations (Assumption 1).

The used methodology for the investigation of As release from_native arsenic by waters consists in testing the validity of Assumptions 1 by following the extent of As release (total As concentration) in the presence of various amounts of $\mathrm{HCO}_{3}^{-}$. To support the discussion, the effects of the mineral particle size and that of selected additives (dolomite, metallic iron and pyrite) on the extent of As release in tap water will be investigated. Therefore, the secondary aim of this study is the characterization of the influence of a carbonate-bearing mineral 
106 (dolomite) and the effect of in situ generated iron species on the As release from an ore

107 material under near-natural conditions.

\section{Materials and Methods}

\section{Solid materials}

110 The used As ore material originates from Otto-Stollen in Breitenbrunn/Erzgebirge (Saxony,

111 Germany). The material was selected on the basis of its high arsenic content (80\%). A

112 qualitative SEM analysis shows the presence of As, Ca, F, Fe, O, S and Si (Fig. SI1 -

113 Supporting Information). The ore material is primary an hydrothermal vein material and

114 arsenic occurred as native arsenic $\left(\mathrm{As}^{0}\right)$ and Loellingite $\left(\mathrm{FeS}_{2}-\mathrm{As}^{-\mathrm{I}}\right)$ [37] in Paragenesis with

115 hydrothermal vein carbonates (for example Fe-bearing Calcite or Dolomite). The mineral was

116 ground to the following particle size fractions: $0.063 \leq \mathrm{d}(\mathrm{mm}) \leq 0.125\left(\mathrm{~d}_{1}\right), 0.200 \leq \mathrm{d}(\mathrm{mm}) \leq$

$1170.355\left(\mathrm{~d}_{2}\right), 0.355 \leq \mathrm{d}(\mathrm{mm}) \leq 0.630\left(\mathrm{~d}_{3}\right), 0.63 \leq \mathrm{d}(\mathrm{mm}) \leq 1.00\left(\mathrm{~d}_{4}\right)$, and $1.0 \leq \mathrm{d}(\mathrm{mm}) \leq 2.0$

$118\left(\mathrm{~d}_{5}\right)$.

119 The used metallic iron ( $\mathrm{Fe}^{0}$-based alloy) is a scrap iron from MAZ (Metallaufbereitung

120 Zwickau, Co.). Its elemental (weight \%) conditions are determined as $3.52 \% \mathrm{C}, 2.12 \% \mathrm{Si}$,

$1210.93 \% \mathrm{Mn}, 0.66 \% \mathrm{Cr}$, and $92.77 \% \mathrm{Fe}$. The materials were fractionated by sieving. The

122 fraction 1.0-2.0 mm was used without any further pre-treatment. The material was used as As-

123 removing agent.

124 Pyrite mineral was crushed and sieved and the fraction 0.315 to $0.63 \mathrm{~mm}$ was used. The 125 elemental composition (weight \%) is: $\mathrm{Fe}: 40 \%, \mathrm{~S}: 31.4 \%, \mathrm{Si}: 6.7 \%, \mathrm{Cl}: 0.5 \%, \mathrm{C}: 0.15 \%$ and

$126 \mathrm{Ca}<0.01 \%$. The material served as a $\mathrm{pH}$ shifting reagent as well as an iron oxide producer

127 (As-removing agent).

128 Dolomite mineral was crushed, sieved and the fraction 0.63 to $1.0 \mathrm{~mm}$ was used. The 129 mineralogical composition (weight \%) is: $\mathrm{SiO}_{2}: 1.2 \%, \mathrm{TiO}_{2}: 0.03 \% ; \mathrm{Al}_{2} \mathrm{O}_{3}: 0.4 \%, \mathrm{Fe}_{2} \mathrm{O}_{3}$ $1300.6 \%, \mathrm{MgO}: 20.24 \%, \mathrm{CaO}: 30.94 \%, \mathrm{Na}_{2} \mathrm{O}: 0.04 \%$. Dolomite is a carbonate mineral; it is 
131 assumed that its dissolution will increase the kinetics of As release [23]. Arsenic adsorption

132 and co-precipitation with carbonate mineral has also been reported [38, 39].

\section{Leaching solutions}

134 To mimic natural conditions various waters were used. Dionised water (DW) was used as a

$135 \mathrm{HCO}_{3}^{-}$free solution (reference system). Table 1 summarizes the carbonate content and 136 simulated effects. The used mineral water $\left(\left[\mathrm{HCO}_{3}{ }^{-}\right]=1854 \mathrm{mg} / \mathrm{L}\right.$ or $\left.30.4 \mathrm{mM}\right)$ contains for 137 instance more than 20 times more $\mathrm{HCO}_{3}{ }^{-}$than the used tape water $\left(\left[\mathrm{HCO}_{3}{ }^{-}\right]=89 \mathrm{mg} / \mathrm{L}\right.$ or 1.4 $138 \mathrm{mM})$. Three technical leaching solutions $(0.1 \mathrm{M})$ partly used for sequential extraction were 139 selected and used for comparison: ethylenediaminetetraacetic acid (EDTA), sodium carbonate $140 \quad\left(\mathrm{Na}_{2} \mathrm{CO}_{3}\right)$, and sulphuric acid $\left(\mathrm{H}_{2} \mathrm{SO}_{4}\right)$.

141 The used tap water (TW) of the city of Göttingen (Lower Saxonia, Germany) has a 142 composition (mg/L) of $\mathrm{Cl}^{-}: 7.7 ; \mathrm{NO}_{3}^{-}: 10.0 ; \mathrm{SO}_{4}{ }^{2-}: 37.5 ; \mathrm{HCO}_{3}^{-}: 88.5 ; \mathrm{Na}^{+}: 7.0 ; \mathrm{K}^{+}: 1.2 ; \mathrm{Mg}^{2+}$ : $143 \quad 7.5 ; \mathrm{Ca}^{2+}: 36$; and an initial $\mathrm{pH} 8.3$.

144 The used spring water (SW) from the Lausebrunnen in Krebeck (administrative district of

145 Göttingen) was used as proxy for natural groundwater. Its composition was (mg/L): $\mathrm{Cl}^{-}:$9.4; $146 \mathrm{NO}_{3}^{-}: 9.5 ; \mathrm{SO}_{4}{ }^{2-}: 70.9 ; \mathrm{HCO}_{3}{ }^{-}: 88.5 ; \mathrm{Na}^{+}: 8.4 ; \mathrm{K}^{+}: 1.0 ; \mathrm{Mg}^{2+}: 5.7 ; \mathrm{Ca}^{2+}: 110.1$; and an initial $147 \mathrm{pH} 7.8$.

148 A commercially available mineral water (MW) was used as proxy for $\mathrm{HCO}_{3}$-rich 149 groundwater. Its composition was $(\mathrm{mg} / \mathrm{L}): \mathrm{Cl}^{-}: 129 ; \mathrm{NO}_{3}^{-}: 0.0 ; \mathrm{SO}_{4}{ }^{2-}: 37.0 ; \mathrm{HCO}_{3}^{-}: 1854$; $150 \quad \mathrm{Na}^{+}: 574 ; \mathrm{K}^{+}: 14.5 ; \mathrm{Mg}^{2+}: 60.5 ; \mathrm{Ca}^{2+}: 99.0 ;$ and an initial $\mathrm{pH} 6.4$.

151 Arsenic release experiments

152 Two different types of batch experiments were conducted:

153 Not homogenized batch experiments: $0.22 \mathrm{~g}$ of the As-bearing ore and 0.0 or $0.11 \mathrm{~g}$ of the 154 additive (dolomite, metallic iron or pyrite) were allowed to react in sealed sample tubes 155 containing $22.0 \mathrm{~mL}$ of the leaching solution at laboratory temperature (about $22{ }^{\circ} \mathrm{C}$ ) for 14 156 days. The tubes had a graduated capacity of $20.0 \mathrm{~mL}$ but were filled to a total volume (22.0 
$157 \mathrm{~mL}$ ) to reduce the head space. The solid:solution ratios were $10 \mathrm{~g} / \mathrm{L}$ for the As-mineral and 5

$158 \mathrm{~g} / \mathrm{L}$ for the additives. After equilibration, $1.0 \mathrm{ml}$ of the supernatant solution was retrieved at 159 the top of each tube for As analysis. To compare the leaching capacity of the tested waters

160 some experiments were conducted with $0.1 \mathrm{M}$ EDTA, $\mathrm{H}_{2} \mathrm{SO}_{4}$, and $\mathrm{Na}_{2} \mathrm{CO}_{3}$.

161 Air homogenized batch experiments: These experiments were conducted in special reaction

162 vessels allowing the system to be homogenized by a humid current of air supplied by a small

163 aquarist pump. The goal was to homogenize the experimental systems at atmospheric pressure $164\left(\mathrm{P}_{\mathrm{CO} 2}=0.035 \%\right)$ without breaking down the materials. $10 \mathrm{~g} / \mathrm{L}$ of the As-bearing ore of 165 various particle sizes and 0 or $5 \mathrm{~g} / \mathrm{L}$ of dolomite, metallic iron, pyrite were allowed to react in 166 sealed vessels containing $100 \mathrm{~mL}$ of tap water at laboratory temperature (about $22{ }^{\circ} \mathrm{C}$ ) for up 167 to 99 days. At given dates $1.5 \mathrm{ml}$ of the solution was retrieved and diluted for As analysis and 168 the same volume of tap water was added to the system.

169 The $\mathrm{pH}$ value was recorded at selected dates. The redox potential was not recorded based on 170 the mineral composition and previous works showing their insignificant variation under the 171 experimental conditions [40, 41].

\section{Analytical method}

173 Analysis for As was performed by inductively coupled plasma mass spectrometry (ICP-MS) 174 at the Department of Geochemistry (Centre of Geosciences, University of Göttingen). All 175 chemicals used for experiments and analysis were of analytical grade.

176 The $\mathrm{pH}$ value was measured by combination glass electrodes (WTW Co., Germany). The 177 electrodes were calibrated with five standards following a multi-point calibration protocol and 178 in agreement with the new IUPAC recommendation [42].

179 Not homogenized batch experiments were performed in triplicate. Error bars given in the 180 figures represent the standard deviation from the triplicate runs. 


\section{Results and Discussion}

183 Effect of leaching solution $\left(\mathrm{HCO}_{3}{ }^{-}\right.$content $)$

184 The processes that enable As to be dissolved and leached from the ore body are known and 185 used in the hydrometallurgy $[43,44]$. To access the reactivity of materials for As retention or 186 removal in the laboratory, many operational leaching solutions have been defined for various 187 sequential extraction schemes [45-48]. All these solutions are more aggressive than natural waters. To check the ability of natural waters to leach As from the studied ore material, parallel experiments were conducted with different waters (Table 1) and the results were compared with that of $0.1 \mathrm{M}$ EDTA, $0.1 \mathrm{M} \mathrm{Na}{ }_{2} \mathrm{CO}_{3}$ and $0.1 \mathrm{M} \mathrm{H}_{2} \mathrm{SO}_{4}$. Table 2 and Fig. 1 summarise the results. It can be seen from Tab. 2 that the $\mathrm{pH}$ value variation was less than 2

$192 \mathrm{pH}$ units for all waters. Therefore, despite considerable variations in the $\mathrm{HCO}_{3}{ }^{-}$content $(0.0$ to

$19330 \mathrm{mM}$ ), the experiments were conducted in the $\mathrm{pH}$ range (4.0 to $9.5-$ Tab. 2) relevant for natural systems. It can be seen that As release was fairly constant to $112 \mathrm{mg} / \mathrm{L}(1.5 \mathrm{mM})$ as the $\mathrm{HCO}_{3}{ }^{-}$contents varies from 0.0 to $30 \mathrm{mM}$. Therefore, assumption 1 (influenced As release with increasing $\mathrm{HCO}_{3}^{-}$) is not verified. Moreover, the leaching behaviour of $0.1 \mathrm{M} \mathrm{Na}_{2} \mathrm{CO}_{3}$

$197(\mathrm{pH}>9.5 ; 100 \mathrm{mM}$ carbonate) was not significantly different from that of the system without 198 carbonate (deionised water - Fig. 1a). Assuming that As was fully oxidized to As ${ }^{\mathrm{V}}$, these results may suggest that the surface area provided by $0.22 \mathrm{~g}$ of As-mineral $\left(\mathrm{d}_{3}\right)$ could have been insufficient to significantly influence As solubilization through desorption from the mineral matrix. Therefore, varying the $\mathrm{HCO}_{3}{ }^{-} / \mathrm{CO}_{3}{ }^{2-}$ content has no impact on As release. To 202 check the validity of this hypothesis another experiment with a higher As-mineral mass 203 loading $(20 \mathrm{~g} / \mathrm{L})$ of a more reactive particle fraction $\left(\mathrm{d}_{1}<\mathrm{d}_{3}\right)$ was performed; the results are discussed below. In the experiment with $10 \mathrm{~g} / \mathrm{L}$ base material, the release efficiency with particle size $d_{1}$ was 1.7 times larger than that of $d_{3}$. In doubling the mineral mass loading (20 $\mathrm{g} / \mathrm{L}$ ) a clearer effect of $\mathrm{HCO}_{3}{ }^{-} / \mathrm{CO}_{3}{ }^{2-}$ on As release is expected. Figure 1a shows that only 0.1

$207 \mathrm{M} \mathrm{H}_{2} \mathrm{SO}_{4}$ could significantly enhance As release. Two processes are likely responsible for this 
observation: (i) increased As solubility with decreasing $\mathrm{pH}$, and (ii) the acidic dissolution of 209 the matrix of the ore material [4].

210 The results of the experiment with $20 \mathrm{~g} / \mathrm{L}$ of the As-mineral $\left(\mathrm{d}_{1}\right)$ are presented in Fig. $1 \mathrm{~b}$.

211 Depending on the leaching solution the extend of As release was 3.0 to 7.3 times lower that 212 for As-mineral $\left(d_{3}\right)$. The largest decrease of As release was exhibited by the system with $213 \mathrm{H}_{2} \mathrm{SO}_{4}$. and the lowest in the system with $\mathrm{Na}_{2} \mathrm{CO}_{3}$. The major reason for decrease As release 214 with decreasing particle size is (i) either the agglomeration of particles or (ii) the fact that $215 \mathrm{As}^{0} / \mathrm{As}^{-\mathrm{I}}$ in the ore material was already oxidized to more stable species ( $\mathrm{As}^{\mathrm{III}}, \mathrm{As}^{\mathrm{V}}$ ) as 216 discussed below (next section). Fig. 1b also shows that that the leaching behaviour of waters 217 are very closed $(0.4 \mathrm{mM})$ and higher than the leaching capacity of $\mathrm{H}_{2} \mathrm{SO}_{4}(0.3 \mathrm{mM})$. This 218 result is not surprising because the initial mineral dissolution of the mineral at $\mathrm{pH} 1$ yield 219 elevated concentration of element from the matrix of the ore material (including $\mathrm{Ca}, \mathrm{Fe}$ und $220 \mathrm{Si}$ ) which subsequently precipitated as the $\mathrm{pH}$ increased to the final value of 5.7. During this process As is adsorbed, precipitated or co-precipitated [49, 50]. Therefore, the major mechanism responsible for increased As release in experiments with the coarser ore material $\left(\mathrm{d}_{3}>\mathrm{d}_{1}\right)$ is the higher As solubility at lower $\mathrm{pH}$ values. The value of the $\mathrm{pH}$ at the end of the experiments ( 1.4 for $d_{3}$ and 5.7 for $d_{1}$ ) gives an idea of the extend of the dissolution of the mineral and its matrix (extend of As co-precipitation). Fig. 1b also shows relatively elevated As released in $0.1 \mathrm{M} \mathrm{Na}_{2} \mathrm{CO}_{3}$ in comparison to natural-near waters. This behaviour can be attributed to the displacement of adsorbed As from the matrix of ore material. This conclusion 228 is supported by the fact that the extend of As released in $0.1 \mathrm{M} \mathrm{Na}_{2} \mathrm{CO}_{3}$ was very similar to 229 that in 0.1 M EDTA. EDTA is an unspecific leaching agent which leaches or desorbs metals 230 and metalloids from contaminated materials [51].

231 In conclusion, the effects of $\mathrm{H}^{+}\left(\right.$as $\left.\mathrm{H}_{2} \mathrm{SO}_{4}\right)$, EDTA and $\mathrm{Na}_{2} \mathrm{CO}_{3}$ on the process of $\mathrm{As}^{-\mathrm{I}}$, As ${ }^{0}$ 232 solubilization could be clearly evidenced but no effect of $\mathrm{HCO}_{3}^{-}(0.0$ to $30 \mathrm{mM})$ could be 
233 observed, confirming the results of Neuberger and Helz [25] that As ${ }^{\mathrm{III}}$-carbonate complexes

234 will be negligible in natural waters.

235

\section{Effect of the ore particle size}

Particle size is an important aspect of mineral dissolution [40, 52]. It can be assumed that a range of particle sizes will have varying dissolution rates. The current assumption is the smaller the particle size the quicker the dissolution. The $<2 \mathrm{~mm}$ fractions of the studied Asmineral can be considered as the most "reactive fraction" and five different sub-fractions have been used for this batch experiments. Figure 2 and 3 summarize the results.

The results from Fig. 2a confirm the general assumption that "the smaller the particle size, the faster the dissolution rate" $[40,53]$. These results were obtained in not homogenised batch experiments and can be regarded as the initial dissolution rate. Noubactep et al. [41] showed that under these experimental conditions a steady state (pseudo-equilibrium) is obtained for $U$ release only after several months (> 500 days).

Figure $2 \mathrm{~b}$ from air-homogenised batch experiments confirms that this trend is strictly true only for the first few days of the experiment. During this time readily soluble As from all particle sizes is released into the solution. Afterwards, powder agglomeration evidently influence As release behaviour for small particle sizes $\left(d_{i} \leq d_{2}\right)$ as no effort was undertaken to disperse agglomerates. Even when such efforts are made (e.g. sonication) the elimination of powder agglomeration is never completely achieved [54-57]. Agglomeration effects are possibly responsible for the lower extent of As release by the particle sizes $d_{1}, d_{2}$ and $d_{3}$ comparatively to $d_{4}$ and $d_{5}$ (Fig. 2b). Based on the relative abundance of the fraction $d_{3}$ it was used all other experiments. Another argument for decreased As dissolution with decreasing particle size in air-homogenised experiments is the fact that the more reactive fractions might have readily oxidized from $\mathrm{As}^{-\mathrm{I}} / \mathrm{As}^{0}$ which precipitate on the surface of the material and inhibit $\mathrm{As}^{-\mathrm{I}} / \mathrm{As}^{0}$ solubilization. Therefore, in air-homogenised experiments with $\mathrm{d}_{\mathrm{i}} \leq \mathrm{d}_{3}$, the solubility of As oxides (or that of a mixture of native As and As oxides) was characterized. 
Because As oxides are more stable under oxic conditions that native As, the lesser extend of

260 As release is not surprising. The behaviour of As release under oxic conditions (air261 homogenised experiments) supports the assumption that in non-disturbed experiments As ${ }^{-}$ $262 \mathrm{I}^{\mathrm{I}} / \mathrm{As}^{0}$ is oxidized to As ${ }^{\mathrm{III}}$ and $\mathrm{As}{ }^{\mathrm{V}}$.

263 Figure 3 depicts the evolution of the $\mathrm{pH}$ as the function of the time in air-homogenised batch

264 experiments. It can be seen that, as a rule, the $\mathrm{pH}$ value uniformly decreases with increasing 265 reaction time. The initial value is close to 8.3 and the value at the end of the experiment is 266 close to 6.0. The evolution of the system with pyrite is an exception and will be discussed 267 later.

\section{Effect of additives}

269 Another way to qualitatively characterize the effect of reactive material on As release 270 consisted in mixing the rock and an additive in the so-called "air-homogenized batch experiments". Figure 4 summarizes the results of the variation of the As concentration.

272 Figure 4 ( $\mathrm{a}$ and $\mathrm{b}$ ) clearly shows that As release was significantly influence by the presence of

273 metallic iron $\left(\mathrm{Fe}^{0}\right)$, dolomite and pyrite $\left(\mathrm{FeS}_{2}\right)$. All additives lower the extent of As release. In 274 particular the presence of dolomite $\left(\mathrm{HCO}_{3}{ }^{-}\right.$-bearing mineral) does no increase As release.

275 Noubactep et al. [41] reported a substantial increased of U release from a natural rock while using the same dolomite mineral and the same experimental conditions. The retardation of As

277 release by dolomite is due to (i) As adsorption onto used mineral and dolomite, (ii) As co278 precipitation with dolomite mineral $[38,39]$. As discussed above As ${ }^{\mathrm{III}}$-carbonate complexes 279 which would have competed with adsorption and co-precipitation to enhance mineral 280 dissolution (as reported for uranium) should be regarded as negligible. Therefore, decreased $281 \mathrm{As}^{0}$ solubilization in the presence of dolomite can be regarded as a confirmation of the results 282 of Neuberger and Helz [25] that As ${ }^{\text {III }}$-carbonate complexes are negligible in natural waters.

283 The primary mechanism responsible for the retardation of As release in the presence of $\mathrm{Fe}^{0}$ 284 and $\mathrm{FeS}_{2}$ is adsorption onto and co-precipitation with $\mathrm{Fe}^{\mathrm{II}} / \mathrm{Fe}^{\mathrm{III}}$ oxyhydroxides from $\mathrm{Fe}^{\mathrm{II}}$ 
oxidation $[49,58,59]$. $\mathrm{Fe}^{\mathrm{III}}$ results from $\mathrm{FeS}_{2}$ and $\mathrm{Fe}^{0}$ oxidation. As removal by $\mathrm{Fe}^{0}$ carriers 286 has been widely discussed in the recent literature [6-10, 61] and will not be repeated here. The mechanism of the retardation of As release through $\mathrm{FeS}_{2}$ will be discussed in some details.

Figure 3 shows a $\mathrm{pH}$ decrease in the initial phase of the experiment with pyrite. This is due to pyrite oxidation that normally increases the As solubility as discussed above for $\mathrm{H}_{2} \mathrm{SO}_{4}$.

290 Under the experimental conditions (neutral $\mathrm{pH}$, oxic), however, dissolved $\mathrm{Fe}^{\mathrm{II}}$ ions from 291 pyrite lead upon oxidation by dissolved oxygen to $\mathrm{Fe}(\mathrm{OH})_{3(\mathrm{am})}$ precipitates that are excellent sorbents for As [35]. This fact explains the low As concentration in the initial phase of the experiment (Fig. 4b). After this initial phase (4-5 days), the As concentration progressively increased. From Fig. 3 it can be seen that once the acidification capacity of the pyrite is consumed [61] and the $\mathrm{pH}$ of the system progressively increased. After about 3 weeks, the As concentration start to increase continuously, suggesting that the adsorptive capacity of in situ produced $\mathrm{Fe}(\mathrm{OH})_{3(\mathrm{am})}$ and that of pyrite by-mineral are consumed while the As-mineral continues to release As into the solution (Fig SI2 - Supporting Information).

\section{Conclusions}

301 This study reiterates that the presence and abundance of bicarbonates ions $\left(\mathrm{HCO}_{3}{ }^{-}\right)$does not 302 have any significant influence on the leaching behaviour of natural waters $(6.0 \leq \mathrm{pH} \leq 9.5)$ for 303 arsenic. Therefore, conflicting results reported for As leaching from sediments [23] may be a 304 misinterpretation of processes occurring in the sediment and yielding increased As release 305 with increasing $\mathrm{HCO}_{3}{ }^{-} / \mathrm{CO}_{3}{ }^{2-}$ concentration. Identifying/discussing these processes was not 306 the aim of this study. Rather, it is shown how the improper consideration of the chemistry of a 307 system may yield troublesome result interpretation which could be propagated in the 308 literature. Therefore, caution may be paid while referencing published results. In particular, 309 the experimental designs and their appropriateness to consistently solve the posed problem 310 should be checked for individual works. In this regard, it should be noticed that Anawar et al. 
311 [23] used $100 \mathrm{mM}$ solutions of $\mathrm{BaCO}_{3}, \mathrm{Na}_{2} \mathrm{CO}_{3}, \mathrm{MnCO}_{3}$, and $\mathrm{NaHCO}_{3}$ (and one gram of

312 sediment) to achieved their results. The carbonates concentration were thereby 3 to 60 times

313 higher as those used in the present work and up to 18 times larger as the concentration of

314 natural waters $(\leq 5.5 \mathrm{mM})$.

315 Since the leaching behaviour of near-natural waters for As is very similar it can be 316 emphasized that the site-specificity for As leaching and transport will mostly depend on the

317 presence of natural organic chelating agents (humic substances) in the aquifer. Furthermore,

318 the composition of the matrix of the As-bearing phase or mineral has to be considered. For 319 example if the matrix contents abundant level of pyrite, its dissolution will yield iron oxides

320 which inhibit/retard As transport within the source area. The most possible precise knowledge 321 of the composition of the matrix and the accurate estimation of the As amount within it will 322 help to properly design a reactive wall for successful remediation.

324 Acknowledgments

325 Dr. T. Heinrichs is kindly acknowledged for the SEM analysis. R. Pfaar (student research assistant) is kindly acknowledged for technical support. The used arsenic-bearing ore was purchased by the Department of Geology of the Technical University Bergakademie Freiberg. The used scrap iron was kindly purchased by the branch of the Metallaufbereitung Zwickau, (MAZ) in Freiberg. The work was partly supported by the Deutsche Forschungsgemeinschaft (DFG-No 626).

\section{References}

333 [1] M. Sadiq, Arsenic chemistry in soils: an overview of thermodynamic predictions and field observation. Water Air Soil Pollut. 1997, 95, 117-136.

335 [2] D. Mohan, C.U. Pittman, Jr., Arsenic removal from water/wastewater using adsorbents A critical review, J. Hazard. Mater. 2007, 42, 1-53. 
[3] H.M. Anawar, A. Garcia-Sanchez, I.S. Regina, Evaluation of various chemical extraction methods to estimate plant-available arsenic in mine soils, Chemosphere 2008, 70, 14591467.

[4] K. Vaxevanidou, N. Papassiopi, I. Paspaliaris, Removal of heavy metals and arsenic from contaminated soils using bioremediation and chelant extraction techniques, Chemosphere 2008, 70, 1329-1337.

[5] D.C. McMurty, R.O. Elton, New approach to in-situ treatment of contaminated groundwaters, Environ. Progr. 1985, 4/3, 168-170.

[6] J.A. Lackovic, N.P. Nikolaidis, G.M. Dobbs, Inorganic arsenic removal by zero-valent iron, Environ. Eng. Sci. 2000, 17, 29-39.

[7] R. Köber, E. Welter, M. Ebert, A. Dahmke, Removal of arsenic from groundwater by zerovalent iron and the role of sulfide, Environ. Sci. Technol. 2005, 39, 8038-8044.

[8] H.L. Lien, R.T. Wilkin, High-level arsenite removal from groundwater by zero-valent iron. Chemosphere 2005, 59, 377-386.

[9] N.P. Nikolaidis, Z. Cheng, A. van Geen, Removal of arsenic from Bangladesh groundwater with zero-valent iron. Am. Chem. Soc. Symp. Series 2005, 915, 361-371.

[10] C. Su, R.W. Puls, Arsenate and arsenite sorption on magnetite: relations to groundwater arsenic treatment using zerovalent iron and natural attenuation. Water Air Soil Pollut. 2008, 193, 65-78.

[11] J.F. Ferguson, J. Gavis, A review of the arsenic cycle in natural waters. Water Res. 1972, $6,1259-1274$.

[12] R. Wagemann, Some theoretical aspects of stability and solubility of inorganic arsenic in freshwater environments. Water Res. 1978, 12, 139-145.

[13] F.N. Robertson, Arsenic in ground-water under oxidizing conditions, south-west United States. Environ. Geochem. Health 1989, 11, 171-185. 
[14] C.C. Fuller, J.A. Davis, G.A. Waychunas, Surface chemistry of ferrihydrite: Part 2. Kinetics of arsenate adsorption and coprecipitation, Geochim. Cosmochim. Acta 1993, $57,2271-2282$.

[15] M. Pantsar-Kallio, P.K.G. Manninen, Speciation of mobile arsenic in soil samples as a function of pH, Sci. Tot. Environ. 1997, 204, 193-200.

[16] M.-J. Kim, J. Nriagu, S. Haack, Carbonate ions and arsenic dissolution by groundwater. Environ. Sci. Technol. 2000, 34, 3094-3100.

[17] J. Matschullat, Arsenic in the geosphere - a review. Sci. Total Environ. 2000, 249, 297312.

[18] P.L. Smedley, D.G. Kinniburgh, A review of the source, behavior and distribution of arsenic in natural waters. Appl. Geochem. 2002, 17, 517-568.

[19] J. Kim, G.V. Korshin, A.I. Frenkel, A.B. Velichenko, Electrochemical and XAFS studies of effects of carbonate on the oxidation of arsenite. Environ. Sci. Technol. 2006, 40, $228-234$.

[20] R.E. Price, T. Pichler, Abundance and mineralogical association of arsenic in the Suwannee Limestone (Florida): Implications for arsenic release during water-rock

[21] K. Stec, A. Bobrowski, K. Kalcher, H. Moderegger, W. Goessler, Determination of arsenic in dolomites with a simple field spectrometric device. Microchim. Acta 2006, $153,45-49$.

[22] S. Wang, C.N. Mulligan, Effect of natural organic matter on arsenic release from soils and sediments into groundwater. Environ. Geochem. Health 2006, 28, 197-214.

[23] H.M. Anawar, J. Akai, H. Sakugawa, Mobilization of arsenic from subsurface sediments by effect of bicarbonate ions in groundwater, Chemosphere 2004, 54, 753-762. minerals: Implications for arsenic mobility. Environ. Sci. Technol. 2003, 37, 4182-4189. 
[25] C.S. Neuberger, Helz G.R., Arsenic(III) carbonate complexing. Appl. Geochem. 2005, $20,1218-1225$.

[26] M.L. Polizzotto, C.F. Harvey, S.R. Sutton, S. Fendorf, Processes conducive to the release and transport of arsenic into aquifers of Bangladesh. Proc Natl Acad Sci USA 2005, 102, $18819-18823$.

[27] P.A. O’Day, Chemistry and mineralogy of arsenic. Elements 2006, 2, 77-83.

[28] R. Vácha, H. Macurová, J. Skála, M. Havelková, J. Ėechmánková, V. Horváthová, Possibilities of some methods for risk assessment of arsenic load in soils. Plant Soil Environ. 2008, 54, 279-287.

[29] W.R. Cullen, K .J. Reimer, Arsenic speciation in the environment. Chem. Rev. 1989, 89, $713-764$.

[30] X. Meng, S. Bang, G.P. Korfiatis, Effects of silicate, sulfate, and carbonate on arsenic removal by ferric chloride, Water Res. 2000, 34, 1255-1261.

[31] X. Meng, G.P. Korfiatis, C. Christodoulatos, S. Bang, Treatment of arsenic in Bangladesh well water using a household co-precipitation and filtration system. Water

[32] R. Höhn, The transport and reaction behavior of arsenic in groundwater: Experiments and case studies. Dissertation, Ruprecht-Karls-University of Heidelberg, 2005.

[33] D.R. Nicholas, S. Ramamoorthy, V. Palace, S. Spring, J.N. Moore, R.F. Rosenzweig, Biogeochemical transformations of arsenic in circumneutral freshwater sediments. Biodegradation 2003, 14, 123-137.

[34] M. Georgiadis, Y. Cai, H.M. Solo-Gabriele, Extraction of arsenate and arsenite species from soils and sediments. Environ. Pollut. 2006, 141, 22-29. of Ferrous Iron and Carbonate on Ferrihydrite and the Mobilization of Arsenic, Environ. Sci. Technol. 2002, 36, 3096-3103. 
414 [36] M.-J. Han, J. Hao, C. Christodoulatos, G.P. Korfiatis, L.-J. Wan., X. Meng, Direct

415 evidence of arsenic(III)-carbonate complexes obtained using electrochemical scanning 416 tunneling microscopy. Anal. Chem. 2007, 79, 3615-3622.

417 [37] R.A. Jones, H.W. Nesbitt, XPS evidence for Fe and As oxidation states and electronic states in loellingite (FeAs2). Am. Mineral. 2002, 87, 1692-1698.

419 [38] G. Román-Ross, G.J. Cuello, X. Turrillas, A. Fernández-Martínez, L. Charlet, Arsenite 420 sorption and coprecipitation with calcite. Chem. Geol. 2006, 233, 328-336.

[39] V.G. Alexandratos, E.J. Elzinga, R.J. Reeder, Arsenate uptake by calcite: Macroscopic and spectroscopic characterization of adsorption and incorporation mechanisms. Geochim. Cosmochim. Acta 2007, 71, 4172-4187.

[40] C. Noubactep, J. Sonnefeld, M. Sauter, Uranium release from a natural rock under nearnatural oxidizing conditions, J. Radioanal. Nucl. Chem. 2006, 267, 591-602.

[41] C. Noubactep, J. Sonnefeld, D. Merten, T. Heinrichs, M. Sauter, Effects of the presence of pyrite and carbonate minerals on the kinetics of the uranium release from a natural rock, J. Radioanal. Nucl. Chem. 2006, 270, 325-333.

[42] R.P. Buck, S. Rondinini, A.K. Covington, F.G.K. Baucke, C.M.A. Brett, M.F. Camoes, M.J. T. Milton, T. Mussini, R. Naumann, K.W. Pratt, P. Spitzer, G.S. Wilson, Measurement of pH. Definition, standards, and procedures (IUPAC Recommendations 2002), Pure Appl. Chem. 2002, 74, 2169-2200.

[43] E.R. Landa, Leaching of molybdenum and arsenic from uranium ore and mill tailings, Hydrometallurgy 1984, 13, 203-211.

[44] E. Virč́kova, J. Fedor, Leaching behaviour of arsenic trisulphide with sodium hydroxide solution, Hydrometallurgy 1991, 27, 1-6. speciation of particulate trace metals. Anal. Chem. 1979, 51, 844-851. 
[46] N.E. Keon, C.H. Swartz, D.J. Brabander, C. Harvey, H.F. Hemond, Validation of an arsenic sequential extraction method for evaluating mobility in sediments. Environ. Sci. Technol. 2001, 35, 2778-2784.

[47] W.W. Wenzel, N. Kirchbaumer, T. Prohaska, G. Stingeder, E. Lombi, D.C. Adriano, Arsenic fractionation in soils using an improved sequential extraction procedure. Anal. Chim. Acta 2001, 436, 1-15.

[48] T.T. Lim, J.H. Tay, J.Y. Wang, Chelating - agent - enhanced heavy metal extraction from a contaminated acidic soil. J. Environ. Engin. 2004, 130, 59-66.

[49] R.J. Crawford, I.H. Harding, D.E. Mainwaring, Adsorption and coprecipitation of single heavy metal ions onto the hydrated oxides of iron and chromium, Langmuir 1993, 9, 3050-3056.

[50] E.R. Landa, A.H. Le, R.L. Luck, P.J. Yeich, Sorption and coprecipitation of trace concentrations of thorium with various minerals under conditions simulating an acid uranium mill effluent environment, Inorg. Chim. Acta 1995, 229, 247-252.

[51] I. Nirdosh, W.B. Trembley, C.R. Johnson, Adsorption-desorption studies on the ${ }^{226}$ Rahydrated metal oxide systems, Hydrometallurgy 1990, 24, 237-248.

[52] M. Malmström, S. Banwart, J. Lewenhagen, L. Duro, J. Bruno, The dissolution of biotite and chlorite at $25^{\circ} \mathrm{C}$ in the near neutral $\mathrm{pH}$ region, J. Contam. Hydrol. 1996, 21, 201213.

[53] S. Çolak, M. Alkan, M.M. Kocakerim, Dissolution kinetics of chalcopyrite containing pyrite in water saturated with chlorine, Hydrometallurgy 1987, 18, 183-193.

[54] M.M. de Villiers, Influence of agglomeration of cohesive particles on the dissolution behaviour of furosemide powder, Int. J. Pharm. 1996, 136, 175-179.

[55] M. Mosharraf, C. Nyström, The effect of particle size and shape on the surface specific dissolution rate of microsized practically insoluble drugs, Int. J. Pharm. 1995, 122, 35 47. 
465 [56] M.G. Orkoula, P.G. Koutsoukos, Variability of dissolution rates at constant

466 undersaturation, J. Colloid Interf. Sci. 2002, 253, 185-189.

467 [57] H. Zhang, P.R. Bloom, E.A. Nater, Change in surface area and dissolution rates during 468 hornblende dissolution at pH 4.0, Geochim. Cosmochim. Acta 1993, 57, 1681-1689.

469 [58] T. Nishimura, Y. Umetsu, Oxidative precipitation of arsenic(III) with manganese(II) and $470 \quad$ iron(II) in dilute acidic solution by ozone. Hydrometallurgy 2001, 62, 83-92.

471 [59] C. Noubactep, Processes of contaminant removal in " $\mathrm{Fe}^{0}-\mathrm{H}_{2} \mathrm{O}$ " systems revisited. The 472 importance of co-precipitation, Open Environ. J. 2007, 1, 9-13.

473 [60] C. Noubactep, A critical review on the mechanism of contaminant removal in $\mathrm{Fe}^{0}-\mathrm{H}_{2} \mathrm{O}$ $474 \quad$ systems. Environ. Technol. 2008, 29, 909-920.

475 [61] C. Noubactep, G. Meinrath, J.B. Merkel, Investigating the mechanism of uranium 476 removal by zerovalent iron materials. Environ. Chem. 2005, 2, 235-242. 
481

482

483

Table 1: $\mathrm{pH}$ value, $\mathrm{HCO}_{3}$-content and simulated conditions of the used waters (n.d.: not determined).

\begin{tabular}{|l|c|c|c|c|c|}
\hline Water & Code & $\mathbf{p H}$ & $\begin{array}{c}{\left[\mathbf{H C O}_{3}{ }^{-}\right]} \\
(\mathbf{m g} / \mathbf{L})\end{array}$ & Simulated conditions & Example \\
\hline Deionized & DW & 5.8 & n.d. & $\mathrm{HCO}_{3}$-poor Water & Rain water \\
\hline Tap & TW & 8.3 & 89 & Current groundwater & Infiltrating R-water \\
\hline Spring & SW & 7.6 & 112 & Current groundwater & Groundwater \\
\hline Mineral & MW & 6.4 & 1854 & $\mathrm{HCO}_{3}$-rich G-water & $\mathrm{HCO}_{3}$-rich $\mathrm{GW}$ \\
\hline
\end{tabular}

Table 2: Variations of the $\mathrm{pH}$ value in the three systems of not homogenized batch experiments using a rock material particle size $\mathrm{d}_{3}(0.355 \leq \mathrm{d}(\mathrm{mm}) \leq 0.630)$. System 2 and 3 were performed with spring water $\left(\mathrm{pH}_{\mathrm{i}} \sim 7.8\right) \cdot \mathrm{pH}_{\mathrm{i}}=$ initial $\mathrm{pH}$ value and $\mathrm{pH}_{\mathrm{f}}=\mathrm{pH}$ value at the end of the experiment. $\Delta \mathrm{pH}=\mathrm{pH}_{\mathrm{f}}-\mathrm{pH}_{\mathrm{i}}$.

\begin{tabular}{|lccc|cc|cc|}
\hline \multicolumn{3}{|c|}{ System 1 } & \multicolumn{2}{c|}{ System 2 } & \multicolumn{2}{|c|}{ System 3 } \\
\hline Solution & $\mathbf{p H}_{\mathbf{i}}$ & $\mathbf{p H _ { \mathbf { f } }}$ & $\Delta \mathbf{p H}$ & $\mathbf{d}_{\mathbf{i}}$ & $\Delta \mathbf{p H}$ & Additive & $\Delta \mathbf{p H}$ \\
& & & & $(\mathbf{m m})$ & & & \\
\hline TW & $8.3_{3}$ & $7.1_{6}$ & $-1.1_{7}$ & $\mathbf{d}_{\mathbf{1}}$ & $-0.4_{3}$ & pyrite & $-0.4_{8}$ \\
SW & $7.8_{4}$ & $7.6_{0}$ & $-0.2_{4}$ & $\mathbf{d}_{\mathbf{2}}$ & $-0.4_{2}$ & $\mathbf{F e}^{\mathbf{0}}$ carrier & $-0.2_{6}$ \\
DW & $5.7_{7}$ & $7.7_{1}$ & $1.9_{4}$ & $\mathbf{d}_{\mathbf{3}}$ & $-0.3_{7}$ & dolomite & $-0.1_{9}$ \\
MW & $6.3_{9}$ & $7.1_{2}$ & $0.7_{3}$ & $\mathbf{d}_{\mathbf{4}}$ & $-0.2_{9}$ & reference & $-0.3_{5}$ \\
\hline
\end{tabular}




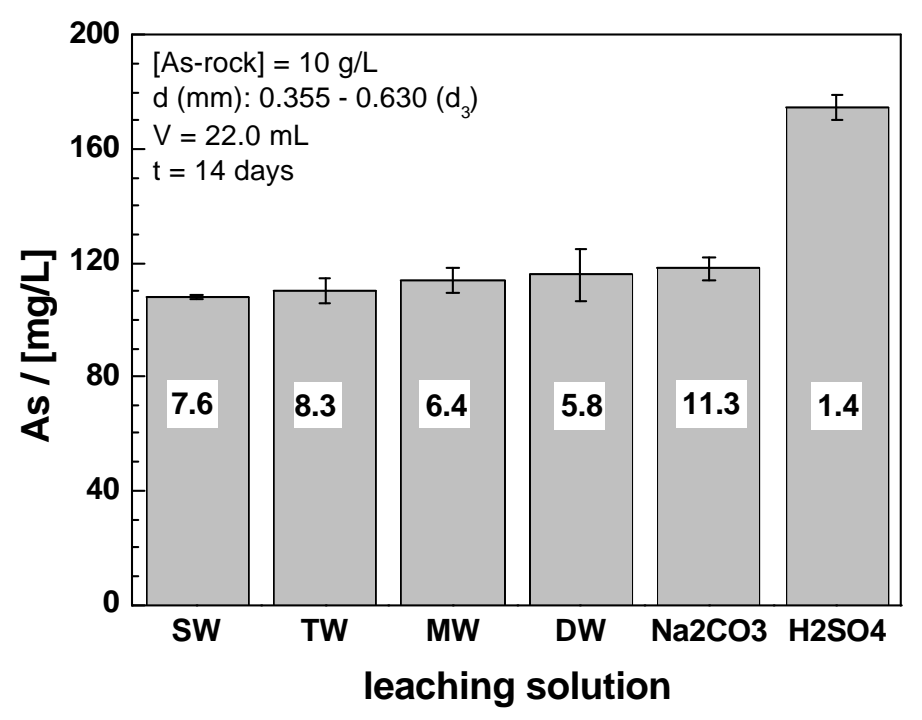

490

491

492

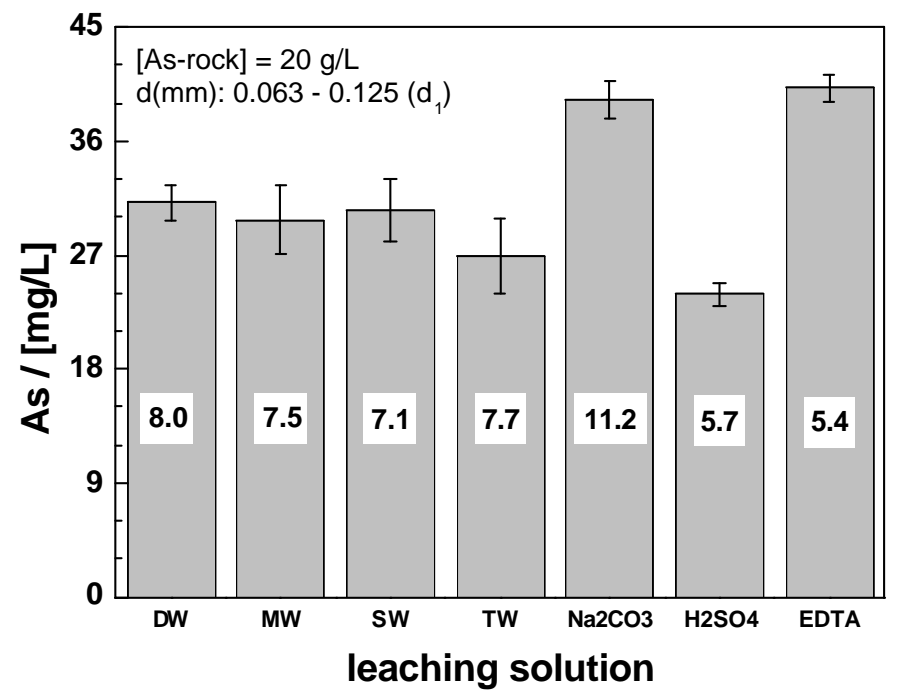

493

494 
496

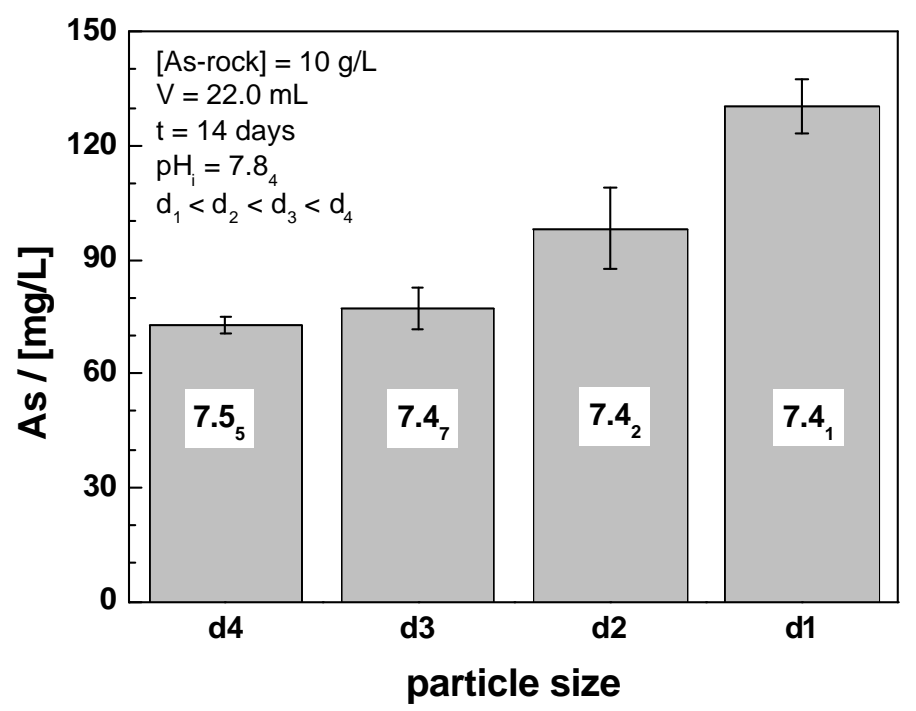

497

498

499

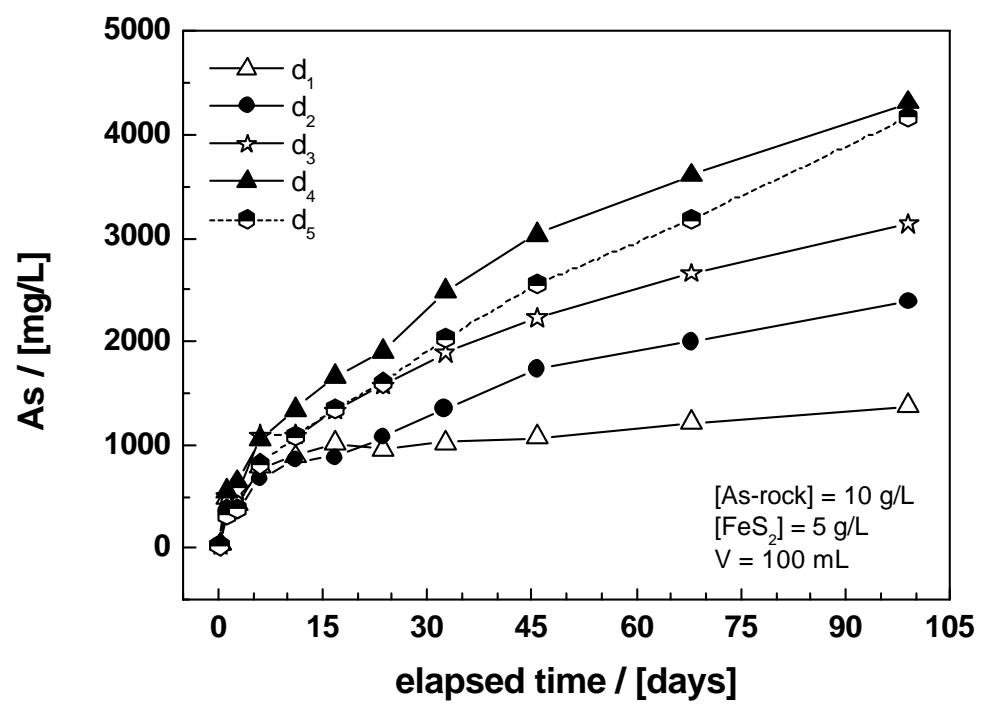

500

501

502 
502

503 Figure 3

504

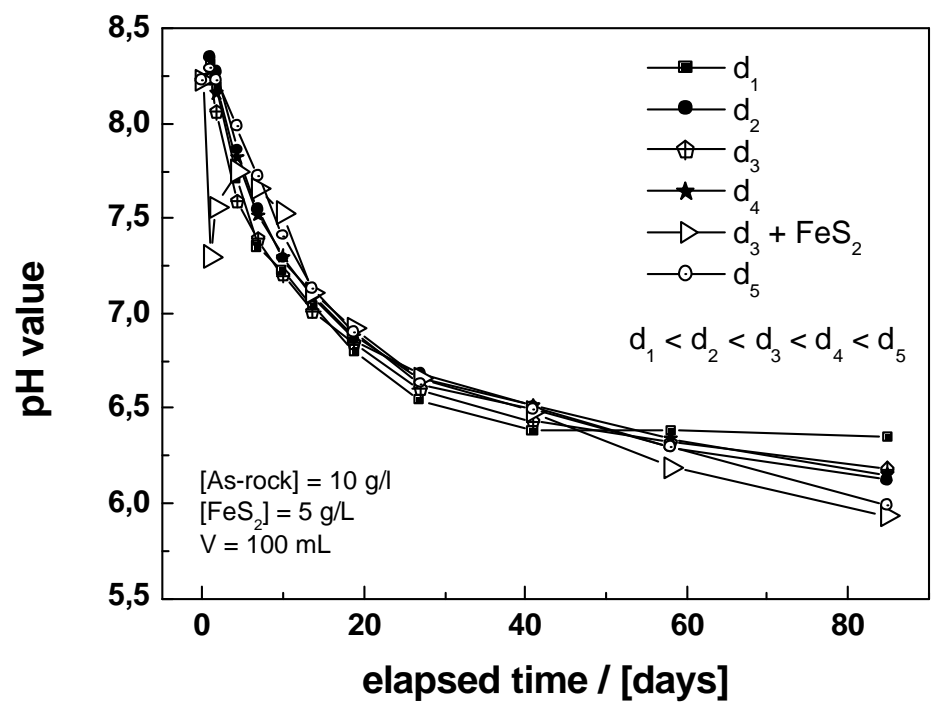

505

506

507

508 
509

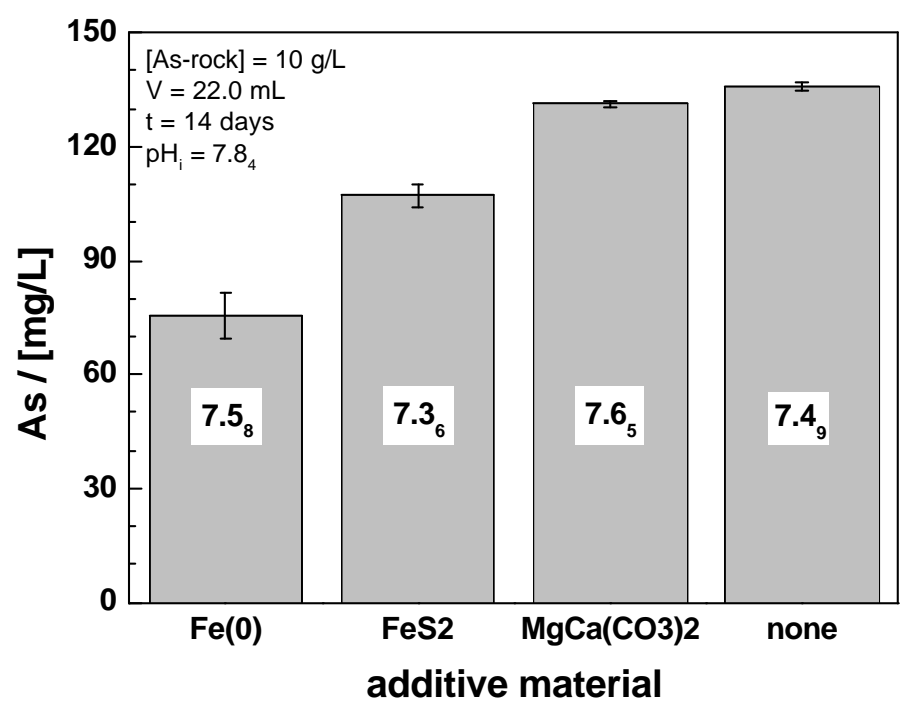

510

511

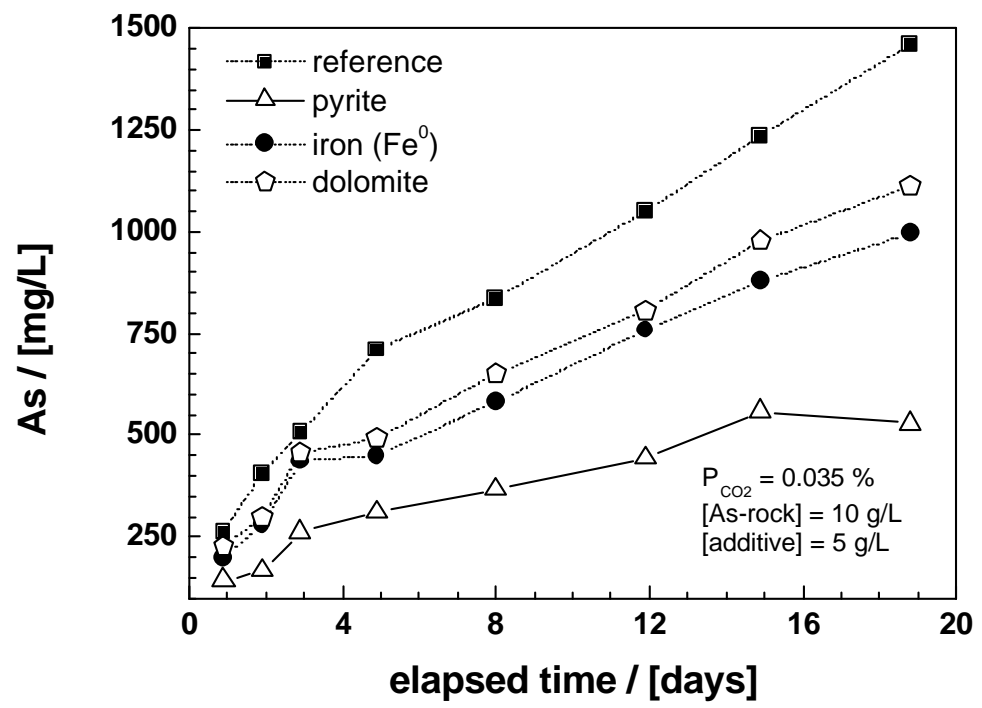

512 


\section{Figure Captions}

\section{Figure 1:}

515 Arsenic release (mg/L) from the As-mineral by different leaching solutions for 14 days in not

516 homogenised batch experiments: (a) $10 \mathrm{~g} / \mathrm{L}$ of As-mineral $\mathrm{d}_{3}$ and (b) $20 \mathrm{~g} / \mathrm{L}$ of As-mineral $\mathrm{d}_{1}$.

517 Error bars provide standard deviations of triplicate experiments. The values in the bars 518 represent the final $\mathrm{pH}$ value of individual leaching solutions.

\section{Figure 2:}

520 Arsenic release $(\mathrm{mg} / \mathrm{L})$ from the base material as function of the rock particle sizes $\left(\mathrm{d}_{\mathrm{i}} \leq 2\right.$ $\mathrm{mm}$ ): (a) in not homogenised batch experiments for 14 days, and (b) in air-homogenised batch experiments. The values on the bars indicated the final $\mathrm{pH}$ (initial $\mathrm{pH}$ 7.8). Error bars provide standard deviations (triplicate experiments). The values in the bars represent the $\mathrm{pH}$ value at

524 the end of the experiment (day 14). The lines are not fitting functions, they simply connect points to facilitate visualization.

Figure 3:

527 Time dependence variation of the $\mathrm{pH}$ value in air-homogenised batch experiments addressing 528 the effect of the rock particle sizes (initial $\mathrm{pH} 8.3$ ). The lines are not fitting functions, they

529 simply connect points to facilitate visualization. The data for the system with pyrite $\left(\mathrm{FeS}_{2}\right)$ are 530 included.

\section{Figure 4:}

532 Arsenic release $(\mathrm{mg} / \mathrm{L})$ as a function of additive material: (a) for 14 days in spring water (not

533 homogenised batch experiments), and (b) for $\leq 19$ days in tap water (air-homogenised batch experiments). The values in the bars represent the $\mathrm{pH}$ value at the end of the experiment (day 14). The not homogenised batch experiments were conducted in triplicate. Error bars give standard deviations. The lines are not fitting functions, they simply connect points to facilitate 537 visualization. 


\section{Supporting Information}

\section{$539 \quad$ Figure SI1}

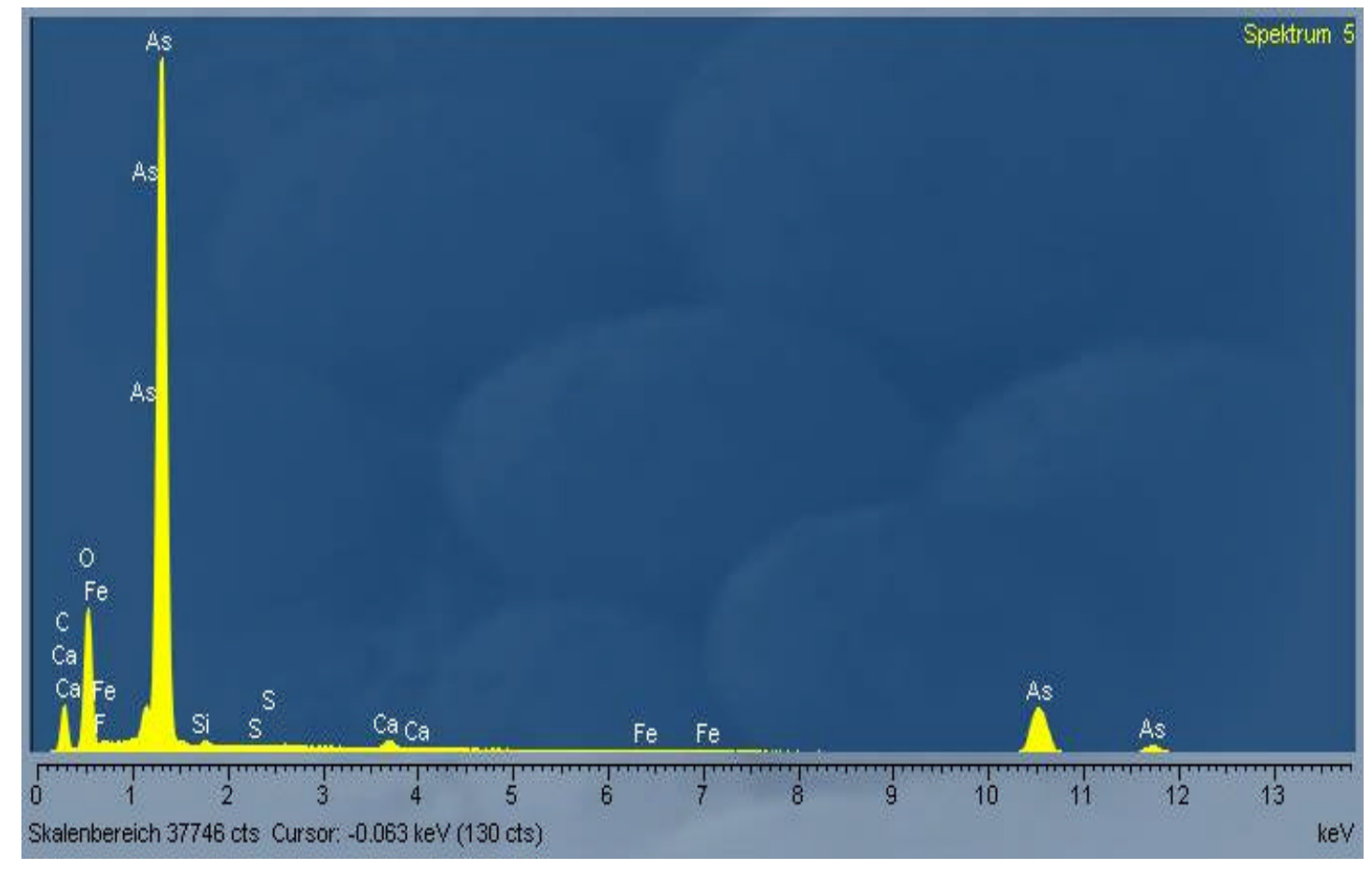

541

542 Figure SI1: Typical SEM spectrum of the surface of the used As-material. The mineral is primary an hydrothermal vein material and arsenic occurred as native arsenic. 


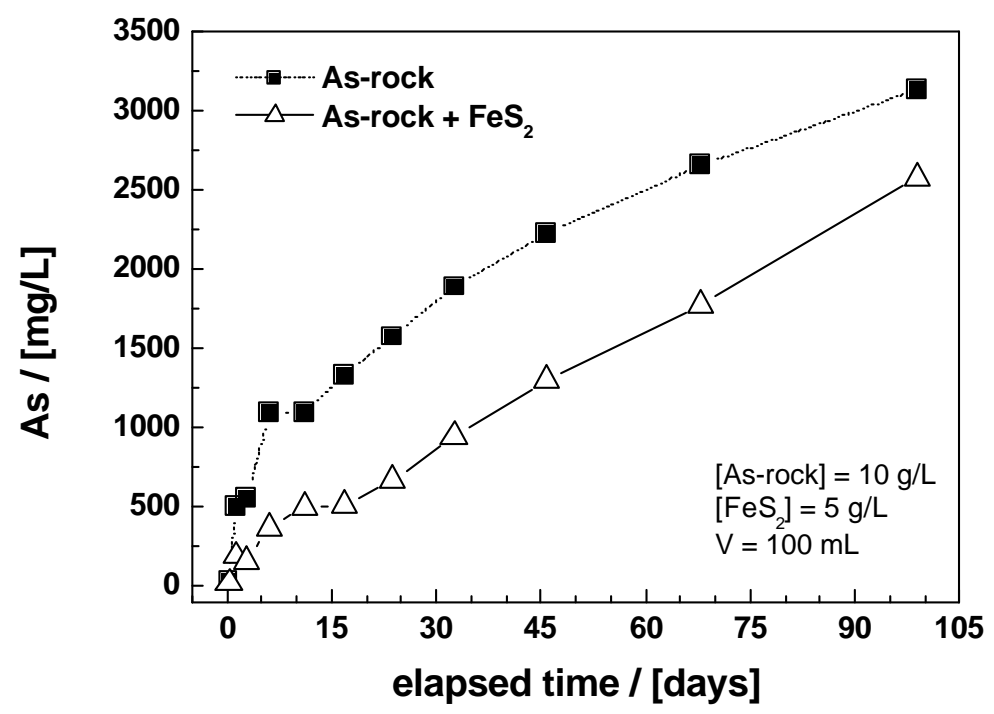

545

547 Figure SI2: Impact of pyrite $\left(\mathrm{FeS}_{2}\right)$ on the evolution of As concentration as function of time in an air homogenized batch experiments for 99 days. $\mathrm{P}_{\mathrm{CO} 2}$ is the atmospheric partial pressure of $\mathrm{CO}_{2}$ (open system). The particle size of used materials was: $0.315 \leq \mathrm{d}(\mathrm{mm}) \leq 0.63$. The represented lines are not fitting functions, they just joint the points to facilitate visualization. 